\title{
Production of chicken sausage (Cobb 500 (Smith, 1992)): caracterisation of Physicochemical, microbiological and sensorial qualities.
}

\author{
KAPCHE LEUNGUE Clotilde Ella ${ }^{1}$, NDIH Aimé Christian ${ }^{1}$, GOUDOUM Augustin ${ }^{1}$, \\ *ABOUBAKAR ${ }^{2}$, ABDOU BOUBA Armand ${ }^{1}$ \& MBOFUNG Carl Moses ${ }^{3}$ \\ ${ }^{1}$ : The University of Maroua, The National Advanced School of Engineering of Maroua. P.O. Box 46 \\ Maroua - Cameroon \\ 2: Departement of Biological sciences \\ 3. The University of Bamenda, School of Technology. P.O. Box 39 Bambili-Cameroon.
}

\begin{abstract}
The aim of this work is to produce chicken sausage, hence, increasing the added value of chicken. The physicochemical and sensorial qualities were evaluated. Microbial quality was investigated during a period of one month under vacuum storage conditions at $4^{\circ} \mathrm{C}$. From the results, it appears that the physicochemical parameters of chicken meat before processing and chicken sausage showed a significant $(\mathrm{p}<0.05)$ difference. The chicken sausage compared to the chicken meat, presents good physicochemical characteristics (an acidic pH of about 5.1, a lowered water content of $67.33 \pm 0.76 \%$ to $60.00 \pm 0.87 \%$ and a relatively high water retention capacity from $28.85 \pm 1.46 \%$ to $69.24 \pm 0.52 \%$ ) for its better preservation. The microbiological quality of chicken sausage was studied over a period of four weeks under one storage condition $\left(4^{\circ} \mathrm{C}\right)$ and showed that the chicken sausage is fairly safe for consumers compared to the recommended levels (absence of salmonella, a total mesophilic aerobic flora of $2.6 .10^{3} \pm 3.8 .10^{2} \mathrm{CFU} / \mathrm{g}$ of product, a rate of Staphylococcus aureus, Escherichia coli respectively $2.05 .10^{1} \pm 3.2$ and $6.8 \pm 3.2 \mathrm{CFU} / \mathrm{g}$ of product) after four weeks chilling storage. The chicken garlic sausage was the best sample appreciated by consumers organoleptically with a percentage of $77.02 \%$. Therefore, processing of chickens in chicken sausage can be a technological center to explore.
\end{abstract}

Keyswords: Chicken, sausage, added value, physicochemical, microbial

\section{I-Introduction}

The current world population is estimated at 7.2 billion and is expected to reach 9.2 billion people in 2050, an increase of 34\% compared to today (Barthes and Jean-Christophe, 2015). This growth will be much more in poor and developing countries. Food demand will therefore continue to increase due to both population growth and rising incomes (Christopher, 2013). Today, the increasing number of hungry people is a global phenomenon that spares no place on the planet. FAO (2015) estimates showed that the number of people suffering from chronic hunger in the world is about 795 million. The challenge at the moment is to ensure food security for millions of hungry people and also to double food production to feed this population. Internationally, it is increasingly recognized that agricultural development is essential if we want to reverse this trend and make significant lasting progress for several million people out of poverty and food insecurity (FAO, 2009). Thus, food production must increase by $70 \%$ and the annual meat production in this percentage must increase by more than 200 million tons to 470 million tons (FAO, 2016). However, increase meat production is not enough to ensure an adequate supply of populations in animal protein. To ensure a continuous and regular supply of meat demand per habitant, technological processing and preservation of these food must be set up by industries in order not only to avoid post-harvest losses, but also to give them added value (USAID, 2013). The transformation allows the continuous supply of processed products consumers respecting uniform standards of safety and quality (Calvin Miller, 2013). 
In many countries, due to the increase of poultry production, many food industries have focused their strategy on innovation and the development of new poultry meat products (Le Guerhie, 2012). Sausages are one of the oldest forms of meat processing. In Cameroon, sausages are only made of cow or pork meat. This is to adapt to the demand of modern consumers who, for better time management, adopt new eating behaviors and make more use of loans to-eat foods like meat products. In this country, the intake of meat products is not diversified because the charcuterie sector remains embryonic and much unstructured. It is in the same vein that was initiated the upgrading of production facilities in order to diversify, increase production, ensure quality, to dock with national and international standards to deal with internal demand and incoming European products. Given the significant evolution of farming in Cameroon and in the poultry sector in particular, reflections should be made on the development of the charcuterie. This is to ensure the conservation, diversification and a steady supply of animal protein to populations and face out of dependence on foreign countries. The chickens from the poultry farms are sold ready to cook after 45 days of breeding. The unfair competition in the poultry production is such that farms are forced to sell their poultry at unfavorable prices and confronted the net losses. The property remains unable to deal with fixed and incompressible charges related to expenditure on the production chain from the farm to the slaughterhouse. Diversification of production through processing of chickens in chicken sausage can be a technological center to explore and palliative to net losses. Therefore, the objective of this work was to produce chicken sausage to increase the added value of chicken in Cameroon.

\section{II-Materials and Methods \\ II-1-Biological materials}

The fresh cut of chicken, Cobb 500 (Smith, 1992) aged 45 days, were used as fresh material for sausage. After arriving from the farm, the chickens are slaughtered, bleeded, and then soaked in water at $52^{\circ} \mathrm{C}$ to facilitate plucking. Chicken are gutted to avoid contamination by viscera. Head and legs are sliced and the rest of the carcass is sprayed with water to minimize contamination. They are then cooled by immersion in water containing ice blocks at a temperature between 0 to $4^{\circ} \mathrm{C}$ for 45 minutes. After cooling, the chickens were boning and flesh obtained was weighed, wrapped in a film and transferred into the cold room for aging for 8 to 12 hours between 0 to $5^{\circ} \mathrm{C}$.

\section{II-2-Sausage preparation and handling}

Ingredients such as spices mixtures, nitrite curing salt, common salt, flour, white pepper, glutamate, binder, cubes were weighed and mixed according to the quantity of flesh obtained; garlic and chilli were weighed and crushed separately. The various ingredients and additives used in the processing of chicken sausage were purchased in Douala Central market (Cameroon).

Chicken sausage formulations consist of $735 \mathrm{~g}$ of cut, $60 \mathrm{~g}$ corn starch, $130 \mathrm{~g}$ ice water, $15 \mathrm{~g}$ table salt, $2 \mathrm{~g}$ of gultamate, $10 \mathrm{~g}$ spices mix, $20 \mathrm{~g}$ garlic powder, $1 \mathrm{~g}$ white pepper powder and $0.5 \mathrm{~g}$ of ascorbic acid. Sausage was then embossed into sausage polyethylene casings using a hand held sausage filling machine. Sausage was dried at $50-55^{\circ} \mathrm{C}$ during $20-25$ minutes. Then hot-smoked at $75^{\circ} \mathrm{C}$ for 60 minutes. It was then chilled in ice water for 5 minutes, vacuum packed (500 g sausage for each pack) and stored at $4^{\circ} \mathrm{C}$ for one month.

\section{II-3-Proximate composition analyses}

The proximate contents of samples were determined according to the Official Methods of Analysis. Moisture content was determined according to the Official Method 950.46 (AOAC, 2002a). Crude protein content (Nx6.25) was calculated using the Kjeldahl method 928.08 (AOAC, 2002b). Lipid (fat) content was determined according to the Soxhlet method 960.39 (AOAC, 2002c). Crude ash (inorganic matter) was determined according to the method 920.153 (AOAC, 2002d). Determination of $\mathrm{pH}$ was done by AFNOR method (1982). Determination of minerals ( $\mathrm{Ca}, \mathrm{Mg}, \mathrm{P}, \mathrm{K}$, and $\mathrm{Na}$ ) was made in the ashes by using (AOAC, 1990) method.

\section{III-4-Analysis of microbiota}


Ten grams of sample were weighed aseptically and homogenized in a Stomacher bag for 1 min with $90 \mathrm{~mL}$ of Maximum Recovery Diluent. Further decimal dilutions were made with the same diluent. Total mesophilic count (TMC) was determined on Plate count agar (PCA, Merck) by the spread plate method, and incubated at $30^{\circ} \mathrm{C}$ for $48 \mathrm{~h}$. Enterococci was counted using KF Agar (Merck) by spread plate method and incubated at $30^{\circ} \mathrm{C}$ for $48 \mathrm{~h}$. Total coliform count (TCC) was made using Violet Red Bile agar (VRBA, Merck) by the spread plate method and incubated at $35^{\circ} \mathrm{C} 24 \mathrm{~h}$. Lactic acid bacteria (LAB) was counted using Man Rugosa Sharp Agar (MRS, Merck) by using spread plate method and incubated at $30^{\circ} \mathrm{C}$ for $48 \mathrm{~h}$. Yeasts and moulds were determined using Potato Dextrose Agar (PDA, Merck) by the spread plate method and incubated at $25^{\circ} \mathrm{C}$ for 7 days. Microbiological counts were all expressed in log and as colony-forming units (CFU/g) of sample (Sekin and Karagözlü, 2004).

\section{II-5-Sensory Analysis}

Sensory analyses were carried out as described by Carbonell et al. (2002). Appropriate sensory descriptors were defined for the sensory experiment and questionnaires were designed including these descriptors. Sausage groups were assessed by a panel of 74 internally trained members, using a $10 \mathrm{~cm}$ line scale, 0 at the extreme left to 10 at the extreme right and rating subsequently scored in $\mathrm{cm}$ from the left. The parameters evaluated by the assessors on samples were: Appearance $(0=$ extremely dislike to $10=$ extremely like $)$, tenderness $(0=$ extremely hard to $10=$ extremely tender $)$, intensity of the spices $(0=$ none to $10=$ extremely intense), juiciness $(0=$ extremely dry to $10=$ extremely juicy $)$, oxidised flavor $(0=$ No oxidised flavour to $10=$ extremely oxidised flavor $)$, and overall level of acceptability $(0=$ extremely unacceptable to $10=$ extremely acceptable). Panelists were also asked to identify a single 'most preferred' sample from those presented.

\section{II-6-Statistical analysis.}

Experimental results were expressed as means with standard deviation. The data were analysed by an analysis of variance $(\mathrm{p}<0.05)$ and the means separated by Duncan's multiple range test with XLSTAT 2014 software (Add-on for Microsoft Excel ${ }^{\circledR}$ of Microsoft Corporation, USA).

\section{III-Results and Discussion}

\section{III-1-Evaluation of physicochemical quality of chicken sausage processing}

The result of the contents of proximate macronutrients and micronutrients analysis of chicken meat and sausage sample is shown in Table 1.

Table 1. Proximal contents of physicochemical analysis chicken meat and sausage.

\begin{tabular}{|l|c|c|}
\hline Contents & Chicken meat & Sausage \\
\hline $\mathrm{pH}$ & $5.73 \pm 0.31^{\mathrm{a}}$ & $5.1 \pm 0.1^{\mathrm{b}}$ \\
\hline Dry Matter (\%) & $32.67 \pm 0.76^{\mathrm{a}}$ & $40 \pm 0.87^{\mathrm{b}}$ \\
\hline Ash (\%) & $0.93 \pm 0.45^{\mathrm{a}}$ & $8.94 \pm 0.34^{\mathrm{b}}$ \\
\hline WRC (\%) & $28.85 \pm 1.4^{\mathrm{a}}$ & $69.24 \pm 0.52^{\mathrm{b}}$ \\
\hline Protein (\% DM) & $18.08 \pm 0.31^{\mathrm{a}}$ & $15.43 \pm 0.48^{\mathrm{b}}$ \\
\hline Lipid (\% DM) & $13.03 \pm 0.17^{\mathrm{a}}$ & $14.52 \pm 0.55^{\mathrm{a}}$ \\
\hline Carbohydrate $(\% \mathrm{DM})$ & $0.098 \pm 0.01^{\mathrm{a}}$ & $1.10 \pm 0.05^{\mathrm{b}}$ \\
\hline Energy (Kcal/100 g) & $189.98^{\mathrm{a}}$ & $196.8^{\mathrm{b}}$ \\
\hline $\mathrm{Ca}(\mathrm{mg} / \mathrm{Kg})$ & $5.43 \pm 0.17^{\mathrm{a}}$ & $14.56 \pm 0.42^{\mathrm{b}}$ \\
\hline $\mathrm{Na}(\mathrm{mg} / \mathrm{Kg})$ & $58.17 \pm 0.54^{\mathrm{a}}$ & $97.87 \pm 0.19^{\mathrm{b}}$ \\
\hline $\mathrm{P}(\mathrm{mg} / \mathrm{Kg})$ & $148.23 \pm 1.08^{\mathrm{a}}$ & $203.27 \pm 2.58^{\mathrm{b}}$ \\
\hline $\mathrm{K}(\mathrm{mg} / \mathrm{Kg})$ & $13.41 \pm 0.32^{\mathrm{a}}$ & $13.52 \pm 0.69^{\mathrm{a}}$ \\
\hline $\mathrm{Mg}(\mathrm{mg} / \mathrm{Kg})$ & $19.97 \pm 0.12^{\mathrm{a}}$ & $25.40 \pm 0.43^{\mathrm{b}}$ \\
\hline
\end{tabular}

pH: Hydrogen Potential, DM: Dry Matter, WRC: Water Retention Capacity, Ca : Calcium ; Na : Sodium ; $P$ : Phosphor ; $K$ : Potassium; Mg: Magnesium.

Averages followed by the same letter in the same line are not different significantly with $P<0.05$ (Test of Duncan). 
It appears from Table 1 that chicken meat and chicken sausage shown a significant variation $(\mathrm{p}<0.01)$ between different contents of macronutrients and micronutrients. The result shows that the $\mathrm{pH}$ value of chicken meat decreases from $5.73 \pm 0.31$ to $5.1 \pm 0.1$ after sausage processing, whereas the Water Retention Capacity (WRC) which increase respectively from $28.85 \pm 1.46$ to $69.24 \pm 0.52$. The sausage present the higher dry matter $(40 \pm 0.87 \%)$ compare to the chicken meat $(32.67 \pm 0.76)$.

During sausage process, evaporation might have resulted to a decrease of moisture content and $\mathrm{pH}$. However, Van Laach and Frans (1990), Smith et al. (1990), Dzudie and Okubanjo (1998) showed that during cooking, there is generally an increase in $\mathrm{pH}$ of the meat products. In this study, the reduction of $\mathrm{pH}$ of the chicken sausage after processing could be due firstly to the salt and in other hand in the incorporated ascorbic acid in the product which, increase the acidity product playing a sizeable role for sausage preservation because the majority of spoilage microorganisms are neutrophils and therefore, do not support acidic $\mathrm{pH}$.

The decrease in water content of the chicken sausage compared to the chicken meat could be due to the evaporation of water during baking (Mbougueng, 2009). In fact the casings used for stuffing the product are synthetic, having a permeable property to gases and water vapor which may therefore justify the loss of water in the chicken sausage at the end of the process.

The increase of water retention capacity of chicken sausage resulting from addition of salt (Kang et al., 2009). The addition of salt increases the hydration of proteins or increases the solubility of proteins such as actin and myosin. The water retention capacity is mainly a function of protein-protein binding interactions that cause an open matrix allowing a higher proportion of total water to be immobilized in the presence of salt. The effects of salt is to dissociate actomyosin, reducing the interactions of these proteins and opening the protein matrix (Kang et al., 2009).

The macronutrients of chicken meat content also differ significantly $(\mathrm{p}<0.01)$ from fresh meat to sausage. The protein value decreased from $18.08 \pm 0.31 \%$ to $15.43 \pm 0.48 \%$. The raised of carbohydrate contents from $0.098 \pm 0.01 \%$ for fresh meat to $1.10 \pm 0.05 \%$ for sausage is noticed.

The reduction of protein content in sausage could be explained by the baking treatment applied to the fray for the chicken sausage. Indeed, under the influence of temperature, the membranes burst, muscle proteins denature and coagulate (Agroscope, 2003). But cooking chicken sausage was made at a temperature of $72^{\circ} \mathrm{C}$ to heart of the product which could therefore justify the loss. This loss is unavoidable since it is primarily the coagulation of protein product and at the same time stabilizing the protein-salt-water system formed with the simultaneous incorporation of a dispersed phase composed of coarse and muscle lipid particles, globules fat, connective tissue, non-soluble proteins and spice particles, etc. The cooking is very important for adhesion between particles which gives to the sausage its desired firm texture. So winning in texture might suffer losing a small amount of protein in exchange.

The increase in carbohydrate content might be due to the wheat flour used during sausage processing which not only improves the texture of the product due to its gelling power and thickening, but also increases its carbohydrate content.

From Table 1, no significant difference was observed between the chicken meat in lipid content and chicken sausage. This result is in contradiction to the assertion of Dzudie and Okubanjo (1998) reporting higher levels of lipid in baked goat sausages and link this increase to the weakening of the collagen of the udder (natural casings) during cooking, facilitating the extraction of lipids and the concentration of the product due to evaporation at a dry cooking. Indeed, the casings used for stuffing before cooking chicken mingled are synthetic, only permeable to gases and water vapor. They are not permeable to other non-volatile components of the product which could justify the constant content of lipids in chicken meat and chicken sausage.

The micronutrients contents showed a significant $(\mathrm{p}<0.01)$ variation between fresh meat and sausage except the potassium content. So Calcium, Sodium, Phosphor, and Magnesium increased respectively from $5.43 \pm 0.17$ to $14.56 \pm 0.42$, from $58.17 \pm 0.54$ to $97.87 \pm 0.19$, from $148.23 \pm 1.08$ to $203.27 \pm 2.58$ and from $13.41 \pm 0.32$ to $13.52 \pm 0.69$ for the fresh chicken meat and chicken sausage due probably to the addition of spices. 
This increase of the mineral content in chicken sausage compared to the chicken due to an increase in its ash content from $0.93 \pm 0.45 \%$ to $8.94 \pm 0.34 \%$ is in contradiction with those obtained by Mbougueng (2009) in beef patties cooked. This author justifies the minerals loss by the reduction of juice through the perforations of the molds used for cooking. Since synthetic casings gas permeable only was used in this case, and therefore it was not shown juice losses during cooking.

The increase in ash content in the chicken sausage could be due to various ingredients used. The food composition table (Ciqual, 2013) showed that wheat flour, all spices, white pepper and garlic have significant mineral contents. What could justify the increase in ash content and therefore since minerals are determined exclusively in the ashes of the product. Thus, an increase in ash content also implies an increase in the mineral content in chicken sausage. Since these ingredients do not have a high content of sodium, increase in sodium content may be due to the addition of salt in the product.

\section{III-2-Effect of technological process on the microbiological quality of chicken sausage}

The microbial qualities of chicken sausage during four weeks chilling storage are shown in Table 2.

Table 2. Evolution of the microbiological flora of the chicken sausage over time.

\begin{tabular}{|l|l|l|l|l|l|}
\hline Days & TMC $\left(\mathbf{1 0}^{\mathbf{3}}\right)$ & TCC $\left(\mathbf{1 0}^{\mathbf{2}}\right)$ & $\begin{array}{l}\text { Yeast and } \\
\text { mold }\end{array}$ & S. aureus $\left(\mathbf{1 0}^{\mathrm{I}}\right)$ & E. coli \\
\hline 0 & $2.63 \pm 0.38^{\mathrm{a}}$ & $7.72 \pm 1.20^{\mathrm{a}}$ & ND & $2.50 \pm 0.32^{\mathrm{a}}$ & $6.8 \pm 3.2^{\mathrm{a}}$ \\
\hline 7 & $2.85 \pm 1.25^{\mathrm{a}}$ & $8.21 \pm 0.40^{\mathrm{b}}$ & ND & $3.45 \pm 0.45^{\mathrm{b}}$ & $7.28 \pm 1.82^{\mathrm{a}}$ \\
\hline 14 & $3.45 \pm 0.75^{\mathrm{b}}$ & $8.76 \pm 0.65^{\mathrm{b}}$ & ND & $4.22 \pm 1.05^{\mathrm{c}}$ & $7.89 \pm 2.35^{\mathrm{ab}}$ \\
\hline 21 & $5.14 \pm 0.80^{\mathrm{c}}$ & $9.52 \pm 1.42^{\mathrm{c}}$ & ND & $6.37 \pm 1.20^{\mathrm{d}}$ & $8.06 \pm 1.74^{\mathrm{ab}}$ \\
\hline 28 & $6.55 \pm 1.20^{\mathrm{d}}$ & $9.88 \pm 1.25^{\mathrm{c}}$ & ND & $6.84 \pm 0.56^{\mathrm{d}}$ & $8.44 \pm 2.50^{\mathrm{b}}$ \\
\hline $\begin{array}{l}\text { Normes }(\mathrm{CE}) \\
\mathrm{n}^{\circ} 2073 / 2005\end{array}$ & $10^{5}$ & $10^{2}$ & ND & $10^{2}$ & 10 \\
\hline
\end{tabular}

TMC : Total mesophilic count, TCC: Total coliform count, ND: non determination.

Averages followed by the same letter in the same column are not different significantly with $P<0.05$ (Test of Duncan).

The result shows that the microbiota in chicken sausage significantly $(\mathrm{p}<0.01)$ increased during chilling storage period. Total mesophilic count (TMC) ranged from $2.63 \pm 0.38\left(10^{3}\right)$ to $6.55 \pm 1.20\left(10^{3}\right)$ respectively at the first day of product and after four week chilling storage. Total coliform count (TCC) of sausage increase from $7.72 \pm 1.20\left(10^{2}\right)$ at the first day of production to $9.88 \pm 1.25\left(10^{2}\right)$ after four week storage. $S$. aureus and $E$. coli show the same variation during chilling storage period.

The quality analysis shown an increase $(\mathrm{p}<0.01)$ of micro flora count during chilling storage. This increased charge of enterococci and coliforms during chilling storage might be due to retardation of the log phase as a result of reduced metabolic rates owing to sudden change in the physical environment (Ozer et al., 2012). Yeast and mold can contaminate chicken meat during handling and processing. The similar result was reported by Ozer et al. (2012) on a fish sausage. However this micro flora increasing during four weeks does not compromise the health of the consumer, because the count remains below the recommended levels compare to European standards.

\section{III-3-Sensorial analysis}

The results of sensorial analysis for chicken sausage sample are presented in Figure 1. 


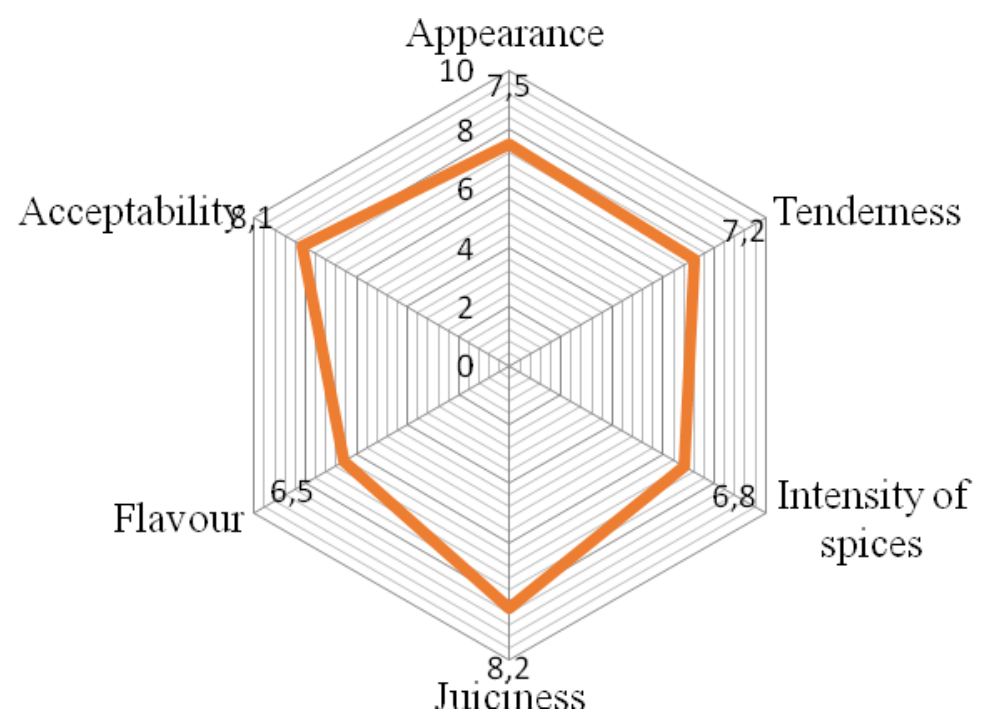

Figure 1. Sensory characteristics of garlic spiced chicken sausage

The appearance tenderness were well perceived by the panelists with 7.5 and 7.2 score respectively. The intensity of the species, juiciness and flavor rated scored higher notes respectively 6.8, 8.2 and 6.5. The acceptability was assessed with grades higher than the average (8.1).

After sensory analysis, chicken garlic sausage spiced was appreciated by the panel. This appreciation could be due to the garlic-spice combination in this sample of chicken sausage which makes it more pleasant as far as garlic is a strong-smelling pungent- tasting bulb. The soft nature of the chicken sausage could be due to the presence of lipid constituents of meat and chicken skin as raw materials for the production of sausages. The main role of these lipids is to emulsify the product after cooking thus making it softer and more palatable (FAO, 2007).

Firm texture of the product could be due in part to the cooking which promotes the gelation of proteins (collagen and elastin) which conduct to a firm texture to the product. Other parts, wheat flour and added binder may also account for the strength of their thinning and gelling properties.

\section{IV-Conclusion}

It may be concluded from this work that the processing of chickens in chicken sausage increased the added value. An evaluation of the physicochemical, nutritional and microbiological characteristics of the chicken meat samples before transformation and the chicken sausage after processing revealed that chicken sausage has a significant and positive influence on the physicochemical and nutritional characteristics of chicken sausage. Microbiologically, chicken sausage was safe for the consumer after one month of storage. Sensorial analysis shown that chicken sausage with spiced garlic was appreciated by consumers from an organoleptic point of view with a percentage of $77.02 \%$ of quotations. The results obtained showed that the chicken sausage has good physicochemical, nutritional, microbiological and organoleptic characteristics to ensure its best preservation for one month.

\section{V-References}

[1] Association of Official Analytical Chemists (AOAC). 1990. Official Methods of Analysis of 15th Ed. Washington.

[2] Association of Official Analytical Chemists (AOAC). 2002a. Moisture content in meat. Official Methods of Analysis 17 th Ed. Washington.

[3] Association of Official Analytical Chemists (AOAC). 2002b. Protein content. Official Methods of Analysis 17 th Ed. Washington.

[4] Association of Official Analytical Chemists (AOAC). 2002c. Fat content. Official Methods of Analysis 17 th Ed. Washington.

[5] Association of Official Analytical Chemists (AOAC). 2002d. Ash content. Official Methods of Analysis 17 th Ed. Washington. 
[6] Barthès, D. and V. Jean-Christophe. 2015. Our planet. Available from http://www.notreplanete.info/actualites. Accessed 14 Aout 2016.

[7] Carbonell, I., L. Izquierdo and E. Costell. 2002. Sensory profiling of cooked gilthead sea bream (Sparus aurata): Sensory evaluation procedures and panel training. Food Sci Technol Int 8: 169-177.

[8] Christophe, M. 2013. World population 2050. Available from notre-planete.info, http://www.notreplanete.info. Accessed 14 Aout 2016.

[9] Dzudie, T. and A. Okubanjo. 1998. Effect of rigor state on quality and stability of goat sausages. Irish J Agr Food Res. 37: 69-77.

[10] Özer, E., M. Ünlüsayin and R. Erdilal. 2012. Microbiological, physicochemical, and sensorial quality of vacuum-packed sausage from thornback ray (Raja clavata L., 1758) at chilled storage. J. Agroaliment. Proc. Technol. 18: 1-7.

[11] FAO. 2007. Meat processing technology for small- to medium scale producers. ISBN: 978- 9747946-99-4 Bangkok, 455.

[12] FAO. 2009. The State of Food and Agriculture. Available from fao.org/docrep/012/i0680f/i0680. Accessed 14 Aout 2016

[13] FAO 2015. State of Food Insecurity in the World 2015. Available from fao.org/3/a-i4646. Accessed 14 Aout 2016.

[14] FCD. 2014. Microbiological criteria applicable from 2015 to private labels, first price marks and raw materials in their initial industrial packaging. Available from 12 . bourgogneiaa.com/.../2014/.../FCD-14-0922. Accessed 10 January 2017.

[15] Le Guerhier, F. 2012. Processing of poultry fat. Available from http://www.fao.org/catalog. Accessed 14 Aout 2016

[16] Mbougueng, D. 2009. Influence of native or acetyl starches of manioc and potato on the physicochemical and textural properties of the beef patty (Bos indicus). Thesis defended at the ENSAI of the University of Ngaoundere, $171 \mathrm{p}$.

[17] Sekin, Y. and N. Karagözlü. 2004. Gida Mikrobiyolojisi Gilda Endüstrisi Icin Temel Esaslar ve Uygulamalar, Klaus Pichhardt 4. Basimdan Çeviri, Luteratür Yayıncılık: 115 Istanboul, 1989, pp. 358

[18] Smith, J. J., H. W. Ockerman and R. F. Plimpton. 1990. The effect of cooking temperature, holding temperature and holding time on proximate analysis, aerobic plate count and coliform count on restructured beef roasts. J. Food Prot. 53(5): 396-399.

[19] Van Laach, R. J. M. and J. M. S. Frans. 1990. Physical, chemical properties and cooking yield of hamburger prepared from accelerated proceeded beef. J. Food Sci. 55: 1268-1269. 